\title{
An Evaluation of Factors Affecting Visual Fine Artists in the wake of COVID-19 towards Economic Empowerment in Kisumu City
}

\author{
Dr. Wagah Mical Ongachi
}

\begin{abstract}
Fine Artists are among the population residing in a cosmopolitan city of Kisumu and they leverage on their skills and talents for economic empowerment.Kisumu city economic empowerment is currently experiencing the highest average urban "poverty levels at $48 \%$ against a national average of $29 \%$. Available statistics indicate that Kisumu, which is net food importer, registers one of the highest incidences of food poverty with $53.4 \%$ of its population living below the food poverty line as compared to Nairobi [8.4\%], Mombasa [38.6\%] and Nakuru [30\%]. Kisumu being the third largest city, yet even Nakuru is a head of it in terms of poverty line it calls for a study to find out the position of Fine Artists who rely on their skills and talents for economic empowerment in the wake of COVI-19. The purpose of this study was to evaluate factors affecting visual fine artists in the wake of covid-19 towards economic empowerment in Kisumu city. The findings revealed that sicknessranked first, followed with low sells of artworks, then displacement from working sites and curfew contributed to the challenges respectively.

Index Terms - Challenges, COVID-19, Empowerment, Fine artist.
\end{abstract}

\section{INTRODUCTION}

Perselli [1993] points out that human consciousness is given shape by images, rhythms, sounds, words which are the tools of the artist. Perselli further notes that the potential power of art as a force for change has long been known to censors and dictators. It is a potential that can be fulfilled once we rediscover and proclaim the rightful and natural place of art and artists in the life of our people. GoK [2018] points out that the economy of Kisumu where we have artists and using art for economic empowerment is currently experiencing the highest average urban "poverty levels at 48\% against a national average of $29 \%$. Available statistics indicate that Kisumu, which is net food importer, registers one of the highest incidences of food poverty with $53.4 \%$ of its population living below the food poverty line as compared to Nairobi [8.4\%], Mombasa [38.6\%] and Nakuru [30\%]. Kisumu being the third largest City yet even Nakuru is a head of it in terms of poverty line it calls for a study to find out the position of Artists who rely on informal business for survival.

In comparison to many of its peer urban centers around the lake,GoK [2018] points out that the growing urban poverty indicators have been aggravated by the reduction of shipping and other transport services between Kenya and Uganda and Tanzania on which artists could have capitalized on them to sell their artworks. Urban poverty in Kisumu manifests itself in reduced living standards, the increasing number of street children, increased informal trade activities of hawking and peddling, increase in commercial sex activities and crime, especially in the low-income settlements. Whether artists are among the $53.4 \%$ people experiencing poverty increase is a question this study had to establish. Major industries in Kisumu such as Kisumu Cotton Mills, Kenya Matches, the Fish processing and Agro-based industries to name a few, have closed down, while some like Kenya Breweries and Muhoroni Sugar Companies have scaled down their operations. Rather than growth and expansion, several plants dealing in manufacturing and processing are either performing dismally, or have closed down, altogether. The parastatal fraternity has not been spared either from this effect as demonstrated by the Kenya Railway Corporation, which was once a major source of transport and jobs, and is currently tottering on the brink of collapse. As from the tenor of governor Prof. Nyongo in 2018 a lot of demolition has taken place in the name of expansion of roads and cleaning the town which has further interfered with business and enhanced poverty index. What is therefore the state of an artist who depends on paint and brush for survival along the stalls that were demolished beginning of the year 2020 coupled with COVID-19?

Artist leverage on the sale of their products such as paintings to both local and foreign tourism. Therefore, it is not clear their economic empowerment survival with the wake of COVID-19 pandemic in Kisumu City. The Travel and Tourism industry is a significant contributor to the economic development of most economies in the world particularly to visual artists who rely on paint and brush. The study was guided by a conceptual framework that looked at the link between environmental factors such as demolition of stalls, low sells of artworks, poor health and curfew in the wake of COVID-19 in relation to informal artists who reside in Kisumu city. The scope of this study was Kisumu City.

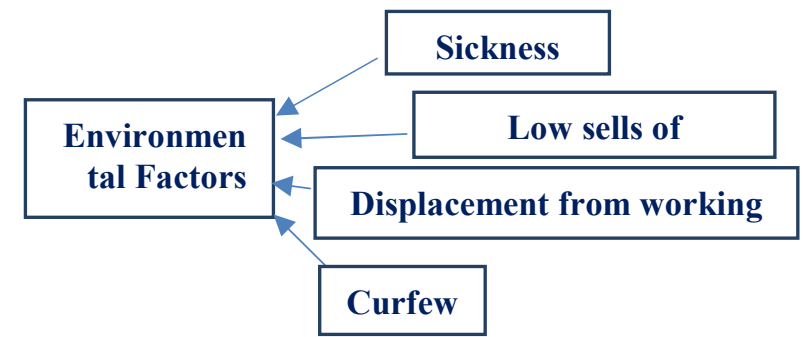

FIG.1:Factors Affecting Visual Fine Artists in the wake of COVID-19 Towards Economic Empowerment in Kisumu 


\section{LITERATURE REVIEW}

Reviewed literature reveals that tourism sector is one of the key economic drivers in Kenya generating $8.8 \%$ of the country's GDP, worth USD 7.9 billion as by 2018 [Standard Media Group, 2019]. This represents a growth of $5.6 \%$, which was greater than the global average of $3.9 \%$ and the Sub-Saharan Africa average of 3.3\%. The industry further contributes about $8.3 \%$ of the total employment, which is equivalent to 1.1 million jobs [Ministry of Tourism \& Wildlife, 2018]. While countries often tend to focus on international tourism due to the revenue earned through exports, domestic tourism remains the leading form of tourism, representing an important tool for regional economic growth and development [WTTC, 2018]. Kenya is the third largest tourism economy in Sub-Saharan Africa after South Africa and Nigeria both of which grew substantially less than Kenya in 2018 [Standard Media Group, 2019]. This impressive performance is threatened by the COVID-19 pandemic that has impacted heavily on travel and tourism worldwide who buy products produced by artists in Kisumu City.

A significant number of countries in Africa have already realized the potentially positive economic impact of domestic tourism and have taken steps to develop and implement domestic tourism strategies [Ndlovu, 2010]. The Ministry of Tourism and Wildlife in Kenya has recognized that domestic tourism is an essential contributor to the growth of Kenya's tourism economy where some of the beneficiaries are artists [Ministry of Tourism \& Wildlife, 2018]. The hotels where tourists stay are all having wall art. Therefore, the need for the development of a domestic tourism Growth Strategy for Kenya, to help tap into the domestic tourism potential to boost the much-needed tourism revenues particularly through artists is key. This recovery strategy outlines strategic actions to sustainably grow and develop domestic tourism. One of the objectives is to increase the number of Kenyans involved in domestic tourism even in the wake of COVID-19. Secondly increase the revenue generated from domestic tourism by increasing expenditure so that artists can leverage on selling their art works. Thirdly maintain tourism resources and infrastructure by addressing seasonality. This therefore calls for an evaluation offactors affecting visual fine artists in the wake of COVID-19 towards economic empowerment in Kisumu city.

A survey by the Kenya Private Sector Alliance [KEPSA, 2020] on the coronavirus pandemic impact on Kenya's economy indicates that $61 \%$ of businesses had been affected by the measures that took place around the world to contain the virus. The survey featured ninety-five [95] locally owned businesses spanning seventeen [17] sectors of the economy. In addition, there were thirty-two [32] manufacturers surveyed by the Kenya Association of Manufacturers [KAM] with the findings integrated into the KEPSA report. According to the report, most businesses expected to be disrupted in these various ways: - Most companies foresaw situation where they will have to ask employees to work from home thus negatively affecting businesses in the service sector, - Stock-outs and delayed deliveries due to the lockdown, - Reduced demand for export products, - Increased cost of goods which consequently increased the overall cost of production, - Reduced capital flows, restrictions on travel, and reduced staff time, - Difficulty in obtaining credit from financial institutions as well as reduced ability to meet their loan interest payments, and, - Slowed investment appetite from foreign and local investors. - The macroeconomic impacts on the key sectors of the economy such as the artists might have faced similar challenges calling for research.

\section{RESEARCH METHODOLOGY}

This study employed descriptive survey design, according to Kothare [2003], descriptive survey focuses on determining the status of a defined population with respect to certain variables. Its primary advantage is that one can gather a great amount of data within a short period of time [Ary,et al, 1996]. It was appropriate for this study because the study dealt with detail description of existing situation intended for justification of current practices that is, what artists in Kisumu City are experiencing in the wake of COVID-19. Kisumu city was chosen because it was experiencing food poverty with $53.4 \%$ of its population living below the food poverty line as compared to Nairobi [8.4\%], Mombasa [38.6\%] and Nakuru [30\%]. The study population consisted of 15 artists who rely on painting as a way of earning a living

\section{A. Sampling Procedure andSample Size}

Snowball sampling technique was used. Mugenda and Mugenda [1999] alludes that snowball sampling is a recruitment technique in which research participants are asked to assist the researcher in identifying other potential subjects and for this case the artists who practiced painting as a form of art. This was because the artist who do painting art do not have established offices where they can be located.

\section{RESULTS AND DISCUSSION}

The study sought out to identify the educational background of artists who do painting in Kisumu city. This was because Education is very necessary for each and every one in order to improve knowledge, way of living as well as social and economic status throughout the life. It helps a person to get knowledge and improve confidence level all through the life. It plays a great role in our career growth as well as in the personal growth particularly when faced with COVI-19 pandemic challenges. 


\section{EDUCATION LEVEL FOR ART PAINTERS}

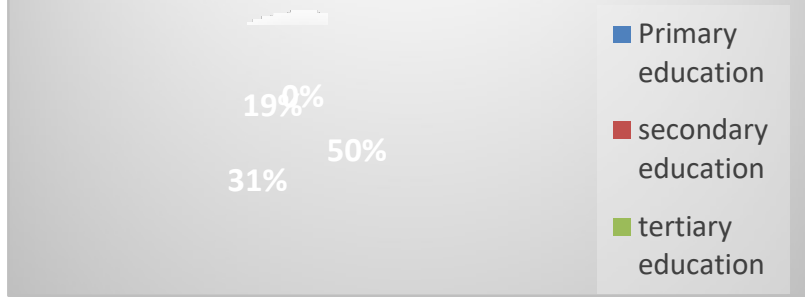

Fig. 2, Education Level for Art Painters in Kisumu City

Fig. 2, reveals that $50 \%$ of Artists who rely on painting for a living were primary school dropout, $31 \%$ were secondary school dropout, $19 \%$ were tertiary institution drop out and none reached university. AL-Shuaibi [2014] confirms that education is the key to success in the future and to have many opportunities in our life. Education has many advantages for people. For instance, it illuminates a person's mind and thinking. It helps one to plan for work or pursue a higher education while graduating from university. In Fig. 2, the study revealed $50 \%$ Artists had Primary education. This is not supported by AL-Shuaibi [2014] who states that having education in an area helps people think, feel, and behave in a way that contributes to their success, and improves not only their personal satisfaction but also their community. In addition, education develops human personality, thoughts, dealing with others and prepares people for life experiences such as in the wake of COVID-19 pandemic. It makes people have a special status in their own society and everywhere they live in. There are various benefits of having education such as having a good career, having a good status in society, and having self-confidence. First of all, education gives us the chance of having a good career in our life. This implies that those who dropped out early in the lowest level such as primary school misses out on many careers' opportunities hence, when caught up with the challenges of COVID-19 their situation becomes unpredictable for survival.

The findings in fig. 2, shows that $30 \%$ artists in Kisumu City had secondary education. AL-Shuaibi [2014] further confirms that with education we can have opportunities for a better employment. This contradicts the findings that reveals that only $30 \%$ artists had secondary education. This implies that many artists who paint in Kisumu city may miss out on employment opportunities. The highly educated we are the better chance we get. Moreover, education polishes our mind, reinforces our thoughts, and strengthens our character and behaviors toward others. It equips us with information in various fields in general and our specialization in particular; especially what we need to master in our job career. Therefore without education we may not survive properly nor have a decent profession and this is a factor contributing to high poverty index from the artist in Kisumu City. Educated people are considered as a valuable source of knowledge for a society. Education makes us view obstacles as challenges to overcome with no fear; facing new things. It is the main factor behind successful people and the merit of developed countries. Therefore, education is deemed a real success behind any future success which contradicts the finding of educational level for artists in Kisumu city. This confirms why they are in informal sector.

\section{Ranking of Challenges in the Wake of COVID-19 IN Kisumu City}

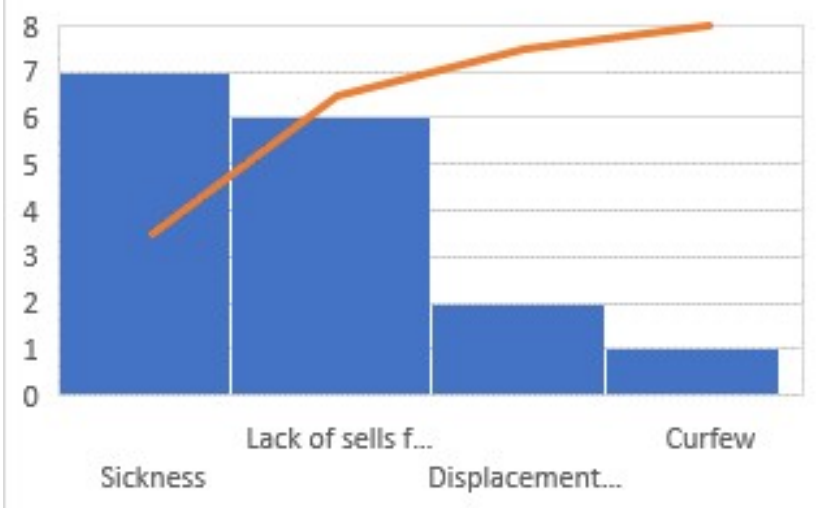

Fig. 3, Challenges Artists Faced in the wake of COVID-19

The artists were to rank the challenges they experienced since the wake of COVID-19 in Kisumu City. Fig. 3, reveals that $90 \%$ ranked sickness as the challenge, $80 \%$ ranked lack of sells for their paintings, 30\% ranked displacement from their working sites, $10 \%$ ranked curfew. Fig.3, shows that sickness was ranked first. Policy Brief [2020] points out that the socio-economic impact of the COVID-19 epidemic operates through two distinct channels. First are the direct and indirect effects of the sickness, which results from when an income-earner such as an artist in the household falls ill, the ratio of active members to dependents falls. The effects may be compounded by lost earnings and taking care of the ill family member, or funeral costs upon death. Ill-health and limited resilience capacities can create multiplier effects. Policy Brief [2020] Further confirms that one study of eleven [11] countries in Sub-Saharan Africa and South and Southeast Asia found that in the absence of health insurance or other forms of universal health coverage, responses to health shocks by people in poverty or near the poverty line commonly included distress sales of assets and taking out loans from informal moneylenders, sometimes at exploitative rates. Thus, the coronavirus will be another source of impoverishment and reinforce existing factors, in turn limiting the ability of vulnerable households to escape from - and stay out of poverty. This confirms that artists who relied on painting as their income in Kisumu City are part of the highest incidences of food poverty with $53.4 \%$ of Kisumu population living below the food poverty line as compared to Nairobi [8.4\%], Mombasa [38.6\%] and Nakuru [30\%].

Fig. 3 revealed $80 \%$ artists lack sells for their paintings. This collaborates with a study done by COVID-19 Research and Evaluation [2020] which points out that the economic effects of the COVID-19 mitigation measures are significant in Kisumu: Over 4 out of 5 participants reported a complete or partial loss of income. Food insecurity is a major threat: $73 \%$ reported skipping a meal or eating less in the last week, more so women [75\%] than men [64\%]. This further confirms that the highest incidences of food poverty with $53.4 \%$ of Kisumu, the artists are part of these population. 
Fig. 3 revealed that $30 \%$ were displaced from their working sites. Business closures -- whether through government bans or business decisions -- result in lost wages for workers in many cases, especially in the informal economy where there is no paid leave. This collaborates with Policy Brief [2020] which confirms that the effects resulting from the fear of catching the virus, which in turn leads to a fear of association with others and reduced labor force participation hence places of employment were closed down. The briefs further point out that there was disruption in transportation this points to the fact that artists could not paint from their usual sites in Kisumu City.

Fig. 3 findings revealed that $10 \%$ of artists who paint ranked curfew as a challenge they faced in the wake of COVID-19. According to Policy Brief [2020] Governments imposed bans on certain types of activities, as when the Government of China ordered factories to shut down or Italy closed most shops throughout the country or the Kenya Judiciary's suspension of court hearings across the country that started on Monday, March 16, 2020 for two weeks in order to allow for further consultations and to design appropriate measures to prevent the spread of the coronavirus. This affected the artists who were locked down in their homes thus becoming a challenge with art production.Health Alert [2021] points out that on June 17, 2021 the Government of Kenya announced further restrictions in response to the worsening of the COVID-19 pandemic in Kisumu. Restrictions were focused on 13 counties declared "hotspot zone" - specifically Busia, Vihiga, Kisii, Nyamira, Kakamega, Trans Nzoia, Bungoma, Kericho, Bomet, Siaya, Kisumu, Homa Bay and Migori. These restrictions in the 13 counties include the following: Public gatherings in the 13 counties are suspended until further notice; The curfew in the 13 counties was restricted from $7 \mathrm{pm}$ to $4 \mathrm{am}$. Other counties were to maintain the existing curfew of $10 \mathrm{pm}$ to 4 am. Except for essential and emergency services, movement between the hotspot Zone and the rest of the country is strongly discouraged; Non-food and livestock markets suspended for 30 days. Employers advised to allow employees to work from home. All physical and worship gatherings was suspended for 30 days. Hospitals must restrict visitors to one individual per patient; All funerals must be held within 72 hours after the confirmation of death, and no more than 50 people may attend a funeral; Weddings may have no more than 30 people attending;

Acknowledgment: The author thanks all the artists in Kisumu City who freely Volunteered valuable information that contributed to the findings of this study

\section{REFERENCES}

[1] Steiner, R., The Story of My Life. London: Anthroposophical Publishing Co, 1928

[2] AL-Shuaibi, A., (2014, The Importance of Education; English Language Center. Community Collage of Qatar)Available:https://www.researchgate.net/publication/26007597 0 The Importance of Education

[3] Ary, D., Jacobs, L.C. \&Razavieh, A., Introduction to Research in Education $\left(5^{\text {th }}\right.$ ed.). Fort Harcort: Bruce Publishers, 1996

[4] COVID-19, Research and Evaluation. Kisumu, Kenya: Adult COVID-19 Perceptions, Prevention Practices andImpact, 2020 Available:https://www.popcouncil.org/uploads/pdfs/2020PGY_Covi d_KenyaAdult_Kisumu.pdf
[5] GoK,2018County Urban Institutional Development Strategy (CUIDS) Kisumu CityAvailable: https://www.kisumu.go.ke/wp-content/uploads/2019/08/Kisumu-Co unty-Urban-Institutional-Development-Strategy-CUIDS-2018-2019final.pdf

[6] Health Alert, Kenya, Government of Kenya Announces New Restrictions.,

2021 Available:https://www.osac.gov/Country/Kenya/Content/Detail /Report/7a340909-d9da-4c91-a04a-1bdd06947ab6

[7] Kenya Private Sector Alliance (KEPSA), Agriculture Sector Business Response to CODIV-19, KEPSA. Nairobi, 17 March 2020

[8] Kothare, C.R., Research Methodology. New Delhi: New Age International (P) Limited Publishers, 2003

[9] Ministry of Tourism \& Wildlife., Kenya Tourism Agenda 2018-2022. Nairobi: Government of Kenya,2018

[10] Mugnda, O.M., \& Mugenda, A.G., Research Methods. Qualitative and Quantitative Approaches. Nairobi: Published by African Center for Technology Studies (ACTS)1999

[11] Ndlovu, J., Strategies for Developing Domestic Tourism: A Survey of Key Stakeholders in Namibia. International Journal of Management, 2010

[12] Odidi,S.B., Odoyo, C.O., Ochola, C.O and Onkwere. K. Socio-Economic Inequalities and Malaria Mobility Experiences among Different Classes of Residents of Kisumu City. Masinde Muliro University, Americal Journal of Social Sciences, 2014, 2[5] 107-114https://www.researchgate.net/publication/339069837_Socio -Economic_Inequalities_and_Malaria_Morbidity_Experiences_am ong_Different_Classes of Residents of Kisumu_City

[13] [13]Perselli, V., (1993). The Importance of being an Artist., Kingstone University, Available DOI:10.1080/10402659308425708https://www.researchgate.net/pub lication/43667730 The importance of being an artist

[14] policy Brief.(2020, Articulating the Pathways of the Socio- Economic Impact of the Coronavirus [COVID-19 Pandemic on the Kenyan Economy).Available: file:///C:/Users/Hp/Downloads/Socio-Economic-Impact-COVID-19Kenya-Policy-Brief-UNDP-Kenya-April-2020.pdf

[15] Standard Media Group. Standard Digital. 2019, 03 13, Available: 04 20, 2020, from https://www.standardmedia.co.ke

[16] Standard Media Group. Standard Digital. 2019, 03 13, Available: 04 20, 2020, from https://www.standardmedia.co.ke

[17] WTTC. Domestic Tourism: Importance and Economic Impact., London: WTTC, 2018 